\title{
Bokmelding
}

\section{Veiledning og oppdagelse}

\author{
Carl Christian Bachke ${ }^{1}$ \\ ${ }^{1}$ Dosent på vernepleierstudiet, Institutt for psykososial helse, Universitetet i Agder \\ E-mail: carl.c.bachke@uia.no \\ Veiledning og oppdagelse \\ Magne Skibsted Jensen, Thorbjørn J. Karlsen \& Geir S. Luthen (Red.), Gyldendal, 2017; 232 sider
}

Dette er en vitenskapelig antologi hvor veiledning belyses - særlig med bruk av postmodernistisk tankegods. Forfatterne er knyttet til utdanningsinstitusjoner på Østlandet, Høgskolen i Innlandet, Høgskolen i Østfold og Norges miljø- og biovitenskapelige universitet. De har solid erfaring fra forsknings- og undervisningsarbeid, og veiledning i disse sammenhenger. Redaktørene sier selv at de «ønsker å tydeliggjøre hva virksom veiledning kan være i ulike kontekster, ...». Videre sies det: «... $\emptyset n s k e r$ vi å invitere til samtale og dialog om veiledningens oppgave sett i lys av postmoderne tenkning.»; og «Antologien representerer et $\varnothing$ nske om å Iøfte frem det ubestemmelige, det uforutsette og det kritiske, som kan gi vilkår for refleksjon og spørsmål som bidrar til å gi mening til profesjon og utdanning.» (s.9).

\section{Innhold}

Antologien består av ti kapitler, fordelt på gode 200 sider. Bak tekstene står i alt ti forfattere, inkludert de tre redaktørene. Kapitteltitlene og avsnittsoverskrifter er assosiasjonsgenererende og får leserens fantasi i sving, ikke minst grunnet bruk av allusjoner og metaforer. Her er noen eksempler:

- Veiledningens handlingsrom og det evige kommende/Å tenke uten rekkverk (kapittel 1)

- «Enhver historie er en spøkelseshistorie»/Narrative spøkelser (kapittel 2)

- «Hot air or useful comments» (kapittel 4)

- Eventyrs handling og symboler som ledetråd i veiledning; herunder begreper som kall, offer, villnis, innvielse, retur, finale og nytt liv (kapittel 7)

Slik språkbruk trigger ulike reaksjoner hos leser/veileder, særlig med tanke på anvendelse av uttrykkene overfor veis $\varnothing$ kere. Noen vil omfavne og la det berike sitt veilednings-repertoar, både teoretisk og praktisk. Andre vil legge det vekk som lite vitenskapelig holdbart, og for lite konkret til å jobbe etter i praktisk veiledning. Den profesjonelle konteksten veilederen opptrer i, vil nok ha noe å si. Personlighetstrekk kan også innvirke - ikke minst graden av utrygghet en tåler å stå i, og hvordan en trives med å være i uoversiktlighet. 
Innholdet kan videre kategoriseres som fagteoretiske og vitenskapsfilosofiske betraktninger eller som empiribaserte beskrivelser av forsknings-utviklingsarbeid. Til den sistnevnte hører:

- Kapittel 4: En intervjustudie av bachelorstudenters opplevelser av oppgavefaglig veiledning

- Kapittel 5: Veiledning og mangfold som støtte i studentstyrte aktiviteter

- Kapittel 6: Språklig oppdagelsesprosesser i nettbasert veiledning i fremmedspråk

- Kapittel 9: Mellom det kjente og det ukjente: Kollektive læringsprosesser på arbeidsplassen

I slike kapitler kan leseren finne eksempler på erfaringer som oppfattes som god veiledning i forhold til gitte fag og virksomhetsområder.

I innledningen lanserer redaktørene sin egen inndelende leseseddel: Kapittel 1-3 fokuserer på muligheter i «veiledningens handlingsrom» til også å gå inn i det ukjente, det uvisse og det uuttalte som kan være vanskelig å ordsette, eller som er (ubevisst) fortiet. De neste tre kapitlene, 4-6, er rettet mot konkrete veiledningsoppgaver i gitte studentsettinger. Så kommer et metaforisk kapittel, 7, hvor eventyrets «klesdrakt» brukes allegorisk som markører i veiledningen. Kap.8-10 agerer som limet opp mot bokens tittel, Veiledning og oppdagelse, med vekt på oppdagelser som kan bidra til forståelser, eller «flere spor å følge» (s.11).

\section{Noen vurderinger}

De tre måtene bokas innhold ovenfor er fortolket delt inn i, kan antyde flere mulige lesetilnærminger og bruksmåter. Hvis en er opptatt av muligheter et billedrikt språk gir i veiledningen, velger en å gå videre på leit etter flere metaforer og språklige nykonstruksjoner fordi en har tro på at dette er til hjelp for de veisøkerne en vanligvis møter. Boka har altså et potensielt forråd for veiledere med ståsted i det språklig-filosofisk fagterreng. Er en veiledningsmessig mer forankret i hva empiri kan åpenbare som sikrere veier å følge i egen veiledning, vil en nok velge å grunne på hva en kan få ut av kap.4-6 + 9. Således har boka budskap til empirikeren, eller den mer naturvitenskapelige forankrede veileder. Den samfunnsfaglige orienterte veileder vil trolig kunne hente noe fra hele boka, men kanskje mest de tre siste kapitlene da de fokuserer det kollektive og kulturelle. Samlet har bokas meny altså appell til veiledere med ulike mat- og mage-preferanser. I mine øyne er det publikasjonens store styrke. Dessuten er det et pre at boka også kan «friste» leseren til å gå utenfor sitt preferanseområde og oppdage rikdommer i andre veilederes grunn-ståsteder - å våge å begynne på en ny begynnelse.

At boka definerer seg så tydelig inn i et postmodernistisk vitenskapsfilosofisk landskap kan ses både som en styrke og en svakhet. Noe av styrken ligger $i$ at forfattere som Larsen bringer til torgs begreper fra andre settinger og språk som vi vanligvis ikke forbinder med veiledningsvokabularet, f.eks. Derridas iterabilitet, aporia, hauntologi, dekonstruksjon og l'invention de l'autre; og Arendts frihetsbegrep med kobling til fremmedordene arkhein og prattein. Slike ord med deres fortolkninger åpner opp for nye refleksjoner om hva veiledning er og hva dens muligheter og hensikter kan være. Ikke minst kan nye uttrykk hjelpe veiledningsaktørene til å se det vanlige med nytt blikk; og vekke yrkesut $\varnothing$ verens sans for det spennende i den «problemfrie praksis». Dessuten bidrar de potensielt til å få norske leseres $\varnothing y n e$ åpnet opp for at veiledningsfaget utvikler seg i andre språk-kulturelle settinger enn den skandinaviske og angloamerikanske. Svakheten består mest $\mathrm{i}$ at mange lesere lett vil kunne misforstå begrepene, grunnet mangelfulle forkunnskaper. Følgelig vil de enten bare bli hoppet over som kuriositeter, eller om de blir fors $\varnothing$ kt inkorporert i leserens veiledningspraksis, bli feilanvendt eller innta en passiv rolle. De mange fremmedordene kan dessuten bli en avsporende måte å gjøre seg interessant på. Blir veiledningen forbedret av om jeg innfører greske ord for begynnelse/fødsel som genau og ginomai (jf. redaktørenes utsagn på side 11: Alltid allerede noen nye begynnelser) og reflektere over skilnaden? 
Bokas tittelord vekker også en undring hos meg: Hvorfor trekker ikke forfatterne eksplisitt veksler på teori om oppdagende læring/læring ved innsikt, jf. Grendstads boktittel fra 1980-tallet (stadig i nye opplag) «Å lære er å oppdage»? Konfluent pedagogikk har sagt mye lignende og parallelt til det jeg oppfatter som antologiens hovedbudskap. Den har dessuten beskrevet en undringsfremmende og dermed oppdagendetilskyndende metodikk. Antydninger til veiledningens hvordan er i stor grad fraværende i antologien. Det fins heller ikke anslag til refleksjonscase, eller andre typer oppgaver å tumle med. Dette forringer antologiens potensiale som lærebok.

\section{Konklusjon}

Antologien har nye spennende vinklinger og termbruk, varierte veiledningsfaglige «retter på sin meny», og ansporer sannsynligvis leseren til å veilede med større inspirasjon i det velkjente. For det vanlige har alltid noe mer i seg som enda ikke er oppdaget. Imidlertid innbiller jeg meg at det metaforrike og filosofipregede språket i noen av kapitlene kan være så utfordrende at den gjennomsnittlige praksisveileder i bachelor-profesjonsstudier synes at innholdet blir så abstrakt at han/hun ikke finner det praksisrelevant. Jeg håper jeg tar feil, for antologien fortjener en stor lesekrets. 